\title{
MAIZE STOVer DegRadation UNDER THE INFLUENCE OF HALOXYFOP-METHYL UNDERDOSES ${ }^{1}$
}

\author{
Degradação da Palhada de Milho sob o Efeito de Subdoses de Haloxyfop-Methyl
}

JASPER, S.P. ${ }^{2}$, VELINI, E.D. ${ }^{3}$, PICOLI JR., G.J. ${ }^{3}$, CARBONARI, C.A. ${ }^{3}$, and SILVA, P.R.A. ${ }^{3}$

\begin{abstract}
One of the major constraints to sustainable tillage is the rapid decomposition of the dry matter. The mechanism known to facilitate this process is the interference in the metabolic pathways of lignin polymers from spraying herbicide underdoses. This study has aimed to verify the effect of underdoses of haloxyfop-methyl in the synthesis of lignin and correlate the interference of this phenolic compound in the decomposition of maize stover. Two preliminary experiments were carried out in a greenhouse to set up the best underdoses to be applied in the yield area experiment. The treatments in the first experiment consisted of: $0 ; 2.5 ; 5$ and $10 \mathrm{~g}$ a.i. $\mathrm{ha}^{-1}$ of haloxyfop-methyl herbicide. And in the second experiment: $0 ; 0.625 ; 1.25$ and $2.5 \mathrm{~g}$ a.i. ha $^{-1}$ of haloxyfop-methyl herbicide. In all treatments were added $0.5 \%(\mathrm{v}: \mathrm{v})$ of the surfactant ethoxylated nonyl phenol + dodecylbenzene sulfonic acid (Aterbane). For the yield area experiment, the underdoses used were 0, 0.625, 1.25 and $2.5 \mathrm{~g}$ a.i. $\mathrm{ha}^{-1}$ of haloxyfop-methyl plus $0.5 \%(\mathrm{v}: \mathrm{v})$ of the surfactant Aterbane. There was an increase in lignin content in the greenhouse experiments with the underdose $0.625 \mathrm{~g}$ a.i. ha-1. In this underdose, change in maize plants growth was not observed. In the field, the concentration of $0.625 \mathrm{~g}$ a.i. ha $^{-1}$ of haloxyfop-methyl increased in $13 \%$ the lignin content without interfering in height and biomass of the plants, contributing to delay the decomposition rate in $4 \%$ in the residual stover.
\end{abstract}

Keywords: Zea mays, herbicide, levels of lignin, growth stimulus.

\begin{abstract}
RESUMO - Uma das maiores limitações para sustentabilidade do plantio direto é a rápida decomposição da matéria seca. O mecanismo conhecido para viabilizar esse processo é a interferência nas vias metabólicas dos polimeros de lignina a partir da aplicação de subdoses de herbicida. Este trabalho teve por objetivos verificar o efeito de subdoses do haloxyfop-methyl na sintese da lignina e correlacionar a interferência desse composto fenólico na decomposição da palhada do milho. Dois experimentos preliminares em casa de vegetação foram conduzidos para ajuste das melhores subdoses a serem aplicadas no experimento em área de produção. Os tratamentos, no primeiro experimento, constituíram-se da aplicação do herbicida haloxyfop-methyl nas subdoses de 0, 2,5, 5 e $10 \mathrm{~g}$ i.a. ha- e, no segundo, nas subdoses de 0, 0,625, 1,25 e 2,5 g i.a. ha- . Em todos os tratamentos foi adicionado $0,5 \%(v: v)$ do surfatante nonil fenol etoxilado+ácido dodecilbenzeno sulfônico (Aterbane). Para o experimento em área de produção, foram utilizadas as subdoses de 0, 0,625, 1,25 e 2,5 g i.a. ha-1 de haloxyfop-methyl, acrescidas de 0,5\% (v:v) do surfatante Aterbane. Houve aumento no teor de lignina nos experimentos conduzidos em casa de vegetação na subdose de 0,625 g i.a. ha-1. Nesta subdose não foi observada alteração no crescimento nas plantas de milho. No campo, a concentração de 0,625 g i.a. ha $\mathrm{h}^{-1}$ do haloxyfop-methyl aumentou em 13\% o teor de lignina sem interferir na altura e na biomassa das plantas, o que contribuiu para retardar a velocidade de decomposição em $4 \%$ na palhada residual.
\end{abstract}

Palavras-chave: Zea mays, herbicida, lignificação, estímulo de crescimento.

Recebido para publicação em 26.11.2015 e aprovado em 22.2.2016.

Universidade Federal do Paraná, Curitiba-PR, Brasil, <samir@ufpr.br>; ${ }^{3}$ Universidade Estadual Paulista "Júlio de Mesquita Filho", Botucatu-SP, Brasil. 


\section{INTRODUCTION}

The no-tillage system (NTS) has been highlighted as an effective strategy to improve agriculture sustainability in tropical and subtropical regions, helping to minimize soil loss and nutrients losses by erosion (Caires et al., 2006). This tillage system has shown rapid growth in cultivated areas in Brazil, occupying, in the 2011/2012 harvest, about 32 million hectares (FEBRAPDP, 2013).

Despite several approaches that positively quality the no-tillage system, there are factors, particularly with respect to the large amount of stover generated from late harvest maize, hampering the next crops sowing, such as, for example soybeans. This problem would be solved by the introduction of agricultural implementation techniques, but it is certain that there would be an increase in operating costs and increased risk of soil compaction by increased traffic in the crop (Aratani et al., 2006).

For Andreotti et al. (2008), another problem is the rapid decomposition of stover, mainly in tropical regions, and the implementation of crops that produce high amounts of stover is important to consolidate NTS in these regions.

Stover decomposition rate determines its time for remaining on the soil surface. The faster its decomposition, the greater the release rate of nutrients, reducing, however, the soil protection. On the other hand, the higher the lignin content and the $\mathrm{C} / \mathrm{N}$ ratio present in stover, the slower its decomposition (Floss, 2000).

Lignin is a highly complex phenolic molecule that is only less abundant in plants than cellulose. Lignin structure is not yet fully known. It is known that these molecules are formed by the polymerization of paracoumaryl alcohol (also called p-coumaryl alcohol, 4-coumaryl alcohol, 4-hydroxycinnamyl alcohol, or 4-(3-hydroxy-1-propenyl)phenol), coniferyl alcohol and sinapyl alcohol; the ratio of these three compounds results in different types of lignin. This polymerization is associated with cellulose in the cell wall, whose function is to provide stiffness, impermeability and resistance to various types of biotic and abiotic stresses (Eckardt, 2002; Cabané et al., 2004).

The alteration of lignin polymerization and hence its contents would be possible with the use of underdoses of herbicides with positive effects and inhibitory effects at high doses. This ambiguous relationship has clearly defined quantitative characteristics, and established a well-defined range limit between the stimulating and inhibitory effects (Calabrese and Blain, 2009; Cox Júnior, 2009).

Haloxyfop-methyl is recommended for weed control of narrow leaves, in large leaf crops; it has an unknown mode of action in relation to the effect in underdoses (Jasper et al., 2015). There are no scientific reports that relate lignin polymerization and exogenous application of haloxyfop-methyl. In specific doses, this molecule has a herbicidal effect, but at lower doses it can be metabolized by certain plant species (Rendina et al., 1990; Tardif et al., 1996).

Haloxyfop-methyl mode of action occurs by blocking lipids synthesis by inhibiting acetyl-coenzyme A carboxylase (ACCase) enzyme, affecting the first stage of acetylcoenzyme A (acetyl-CoA) conversion to malonyl-CoA. Malonyl-CoA is a precursor substance of metabolites essential to cell structure and protection of plants. This enzyme is responsible for the synthesis of flavonoids and anthocyanins, long chain fatty acids and also malonate used in ethylene synthesis (Sazaki and Nagano, 2004).

Because of the importance of the lignin polymerization process in plants and especially its relationship with NTS, this study aimed to verify the effect of underdoses of haloxyfopmethyl in the synthesis of lignin and correlate the interference of this phenolic compound in the decomposition of maize stover.

\section{MATERIALS AND METHODS}

The work materials used were maize seeds (Zea mays Hybrid 2B587Hx - Herculex) and herbicide Verdict* $\mathrm{R}\left(124,7 \mathrm{~g} \mathrm{~L}^{-1}\right.$ a.i. of haloxyfop-methyl). In 2011, two experiments were conducted in a greenhouse, according to Schabenberger et al. (1999), to determine underdoses of herbicide for a field experiment. 
The experiment in yield area was conducted in $2011 / 2012$.

\section{Experiments in a greenhouse}

In both experiments, the design adopted was completely randomized with four replications. Each experimental unit consisted of a $(5 \mathrm{~L})$ plastic pot filled with substrate Plant $\operatorname{Max}{ }^{\circledR}$, in which the seeds were sown. The treatments studied in the first and second experiments are shown in Table 1. In all treatments, $0.5 \%(\mathrm{v}: \mathrm{v})$ of surfactant nonylphenol ethoxylate + dodecylbenzene sulfonic acid (Aterbane) was added.

Table 1 - Underdoses of haloxyfop-methyl in the first and second experiments conducted in a greenhouse. Botucatu/ SP, 2012

\begin{tabular}{|l|c|c|c|c|}
\hline \multirow{2}{*}{ Experiment } & \multicolumn{4}{|c|}{ Underdoses of haloxyfop-methyl $\left(\mathrm{g}\right.$ a.i. $\left.\mathrm{ha}^{-1}\right)$} \\
\cline { 2 - 5 } & $\mathrm{T} 0$ & $\mathrm{~T} 1$ & $\mathrm{~T} 2$ & $\mathrm{~T} 3$ \\
\hline First & 0.0 & 2.5 & 5.0 & 10.0 \\
\hline Second & 0.0 & 0.625 & 1.25 & 2.5 \\
\hline
\end{tabular}

Applications of haloxyfop-methyl with surfactant in both experiments were performed at 28 days after sowing (DAS), when the maize plants were in vegetative stage V4. The procedure was performed with a stationary sprayer coupled to a spray boom containing four DG 10 11002-type nozzles, with spacing among nozzles of $0.5 \mathrm{~m}$ and positioned at $0.5 \mathrm{~m}$ of the target height. The system was operated with a displacement speed of $3.6 \mathrm{~km} \mathrm{~h}^{-1}$ at a constant pressure (1.5 bar - pressurized with compressed air), and the spray mix volume was the one corresponding to the volume of $200 \mathrm{~L} \mathrm{ha}^{-1}$. The temperatures at the time of application were 22 and $19{ }^{\circ} \mathrm{C}$, relative humidity of $65 \%$ and $72 \%$ for the first and second experiments, respectively.

\section{Experiment in a yield area}

The geographical coordinates of the experimental area were $22^{\circ} 41^{\prime}$ of south latitude and $48^{\circ} 34^{\prime}$ ' of west longitude, with an average altitude of $770 \mathrm{~m}$, and the climate was classified, according to Köppen climate classification, as Cwb.
In this experiment, maize seeds were sown in clayey soil containing 165, 385 and $450 \mathrm{~g} \mathrm{~kg}^{-1}$ of sand, silt and clay, respectively. The experimental design adopted was a randomized block with four replications. Each experimental unit was ten-meter long and four-meter wide, consisting of four sowing rows spaced 0.85 meters, with a density of 70,000 seeds per hectare. On the basis fertilization, $300 \mathrm{~kg} \mathrm{ha}^{-1}$ of fertilizer formula 08-28-16 were used and, on topdressing, $300 \mathrm{~kg} \mathrm{ha}^{-1}$ of urea, split in two applications of $150 \mathrm{~kg} \mathrm{ha}^{-1}$ each, according to an agronomic recommendation. In the border areas of the plots, maize was also sown to avoid contamination between the experimental units. The treatments consisted of the application of the haloxyfop-methyl herbicide in underdoses: $0,0.625,1.25$ and $2.5 \mathrm{~g}$ a.i. ha $^{-1}$ (the same underdoses applied in the second experiment in a greenhouse). In all treatments that received application of herbicides, 0.5\% (v:v) of surfactant Aterbane ${ }^{\circledR}$ was added. The application of the treatments was done at 28 (DAS), with the maize plants in a vegetative stage V4, with a knapsack sprayer pressurized at $\mathrm{CO}_{2}$, keeping at a constant pressure of $2.0 \mathrm{kgf} \mathrm{cm}^{-2}$, equipped with a 2 meter spray boom with four Teejet XR 11002 VS spraying nozzles, spaced $0.5 \mathrm{~m}$, adjust to apply a $200 \mathrm{~L} \mathrm{ha}^{-1}$ of spray mix. The temperature at the moment of application was $28{ }^{\circ} \mathrm{C}$, with relative humidity of $90 \%$ and air velocity of $10 \mathrm{~km} \mathrm{~h}^{-1}$.

\section{Characteristics evaluated}

The heights of the maize plants were measured from the ground to the insertion of the last fully expanded leaf, after 21 days of application (DAA) in a greenhouse and 150 DAA in the yield area. Then, the plants collected were placed in paper bags, weighed and left in a forced circulation oven at $60{ }^{\circ} \mathrm{C}$ for seven days. The dried material was weighed, the biomass was determined, and the yield calculation was converted per hectare. The leaves were ground in a circular rotor mill with knives (Marconi MA340).

The lignin content, obtained from the dry matter, was quantified in the cell walls free from proteins, according to the methodology by Morrison (1997). About $100 \mathrm{mg}$ of sample 
were placed in 6-mL polypropylene cartridges (Applied) for a solid-phase extraction (SPE), and sequentially subjected to washings with the following solutions: water at $100{ }^{\circ} \mathrm{C} ; 3 \%$ aqueous solution of sodium dodecyl sulfate (SDS) at $122{ }^{\circ} \mathrm{C} ; 85 \%$ aqueous solution of ethanol at $75{ }^{\circ} \mathrm{C}$; and acetone at $56{ }^{\circ} \mathrm{C}$. A portion of $20 \mathrm{mg}$ of the material washed was packed in a centrifuge tube, and $500 \mu \mathrm{L}$ of acetyl bromide at $25 \%$ were added. The samples were heated at $70{ }^{\circ} \mathrm{C}$ for $30 \mathrm{~min}$; after this period of time, they were transferred to an ice bath and then neutralized by adding $0.9 \mathrm{~mL}$ of $\mathrm{NaOH} 2 \mathrm{M}$. Subsequently, $0.1 \mathrm{~mL}$ of hydroxylamine and $2 \mathrm{~mL}$ of glacial acetic acid were added. The samples were centrifuged at $1,000 \mathrm{xg}$ for 5 minutes and the supernatant was submitted to a spectrophotometric reading (UV/VIS GBC, model Cintra 40) at $280 \mathrm{~nm}$. The lignin concentration was obtained based on the lignin standard curve (Sigma), under the same conditions of the sample, and expressed in mg of lignin per gram of cell wall.

The amount of topdressing was monitored once a month in all plots to obtain the stover decomposition rate for four months, according to the method described by Penati et al. (2005).

The data were submitted to a polynomial regression analysis with the help of the program SigmaPlot (Systat Software, 2006), according to a methodology by Cedergreen et al. (2005).

\section{RESULTS AND DISCUSSION}

In the first experiment, the underdoses significantly altered the height of maize plants compared to the control; underdose $2.5 \mathrm{~g}^{\mathrm{ha}^{-1}}$ increased the maize plants height in $8.2 \%$ and the ones of 5 and $10 \mathrm{~g} \mathrm{ha}^{-1}$ of haloxyfop-methyl reduced it in 19.0 and $37.6 \%$, respectively (Figure 1A). The maximum height, according to the model adjusted, was $101 \mathrm{~cm}$ with $1.62 \mathrm{~g} \mathrm{ha}^{-1}$. However, an underdose above $3.22 \mathrm{~g} \mathrm{ha}^{-1}$ of haloxyfop-methyl promoted a significant reduction in plants height.

Underdoses of 0.625 and $1.25 \mathrm{~g} \mathrm{ha}^{-1}$ significantly increased maize plants height in 8.0 and $5.6 \%$, respectively (Figure 1B). An underdose of $2.5 \mathrm{ha}^{-1}$ has not provided results different from the control. Plant height is a variable much observed in the literature in
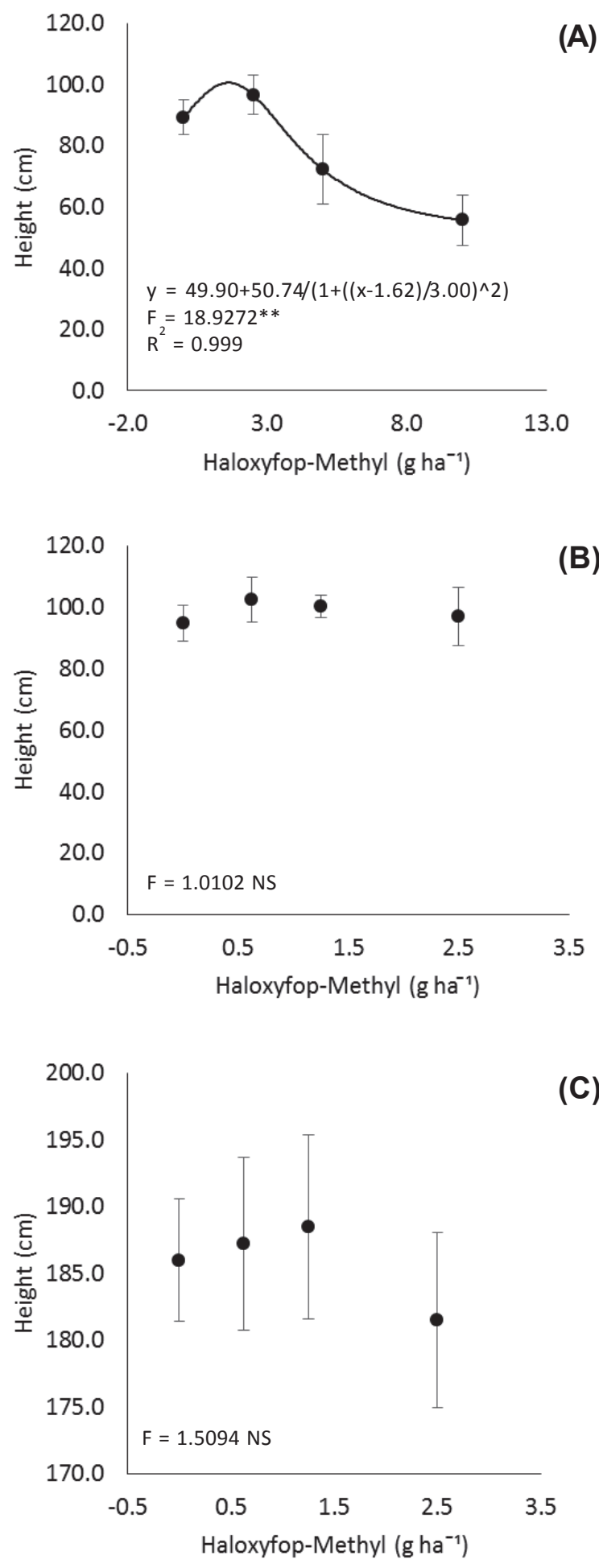

(C)

The data refer to mean \pm standard error $(\mathrm{n}=$ four replications, with four readings; $(\mathrm{p}<0.01)$.

Figure 1 - Height of maize plants. (A) and (B) Experiments in a greenhouse - evaluation at 21 DAA. (C) Experiment in a yield area - evaluation after 150 DAA of haloxyfop-methyl. 
studies on the hormetic effect (Silva et al., 2012) and especially with respect to studies related to glyphosate molecule (Velini et al., 2008). For this experiment in a yield area, there was no significant adjustment to describe the height profile of maize plants in terms of underdoses; therefore, there were no significant differences among the underdoses used (Figure 1C). According to Gomes et al. (2010), maize crops are susceptible to lodging, resulting in world maize annual yield losses of 5 to $20 \%$; therefore, factors that contribute to an unwanted increase such as stimulus of fertilization, hormetic effect, among others, should be carefully assessed.

The accumulation of plant biomass was maximum with underdose $2.01 \mathrm{~g} \mathrm{ha}^{-1}$ (Figure 2A), which resulted in an increase of $23.4 \%$ in the biomass of maize in a greenhouse. Underdoses of 5.0 and $10.0 \mathrm{~g} \mathrm{ha}^{-1}$ reduced 18.7 and $68.0 \%$ of the biomass accumulation, respectively. Therefore, the concentration of $10.0 \mathrm{~g} \mathrm{ha}^{-1}$ was discarded because of the results of significant losses in productivity.

In the second experiment in a greenhouse (Figure 2B), underdoses $0.625,1.25$ and $2.5 \mathrm{~g} \mathrm{ha}^{-1}$ significantly increased the maize biomass $38.9,22.0$ and $7.8 \%$, respectively. In the yield area, the estimate for dry biomass was of $5,800 \mathrm{~kg} \mathrm{ha}^{-1}$ for control plants, and of $5,857,6,226$ and $7,308 \mathrm{~kg} \mathrm{ha}^{-1}$ with the application of underdoses $0.625,1.250$ and $2.500 \mathrm{~g} \mathrm{ha}^{-1}$ of haloxyfop-methyl, respectively (Figura 2C). The results of this hybrid biomass accumulation were lower compared to the experiment conducted by Chioderoli et al. (2010), who obtained $9,652 \mathrm{~kg} \mathrm{ha}^{-1}$ by using irrigation.

In the first experiment, underdoses 2.5, 5 and $10 \mathrm{~g} \mathrm{ha}^{-1}$ increased in $21.8,18.1$ and $9.8 \%$ the lignin content in relation to control, respectively (Figure 3A).

The results of average lignin contents obtained in the second experiment showed an increased profile in underdoses $0,0.625$ and $1.25 \mathrm{~g} \mathrm{ha}^{-1}$, which provided contents of 13.35 , 15.53 and $12.54 \%$ of lignin present in the cell wall, respectively (Figure 3B). For underdose $2.5 \mathrm{~g} \mathrm{ha}^{-1}$ lignin content was $12.54 \%$. The values analyzed made it possible to adjust a

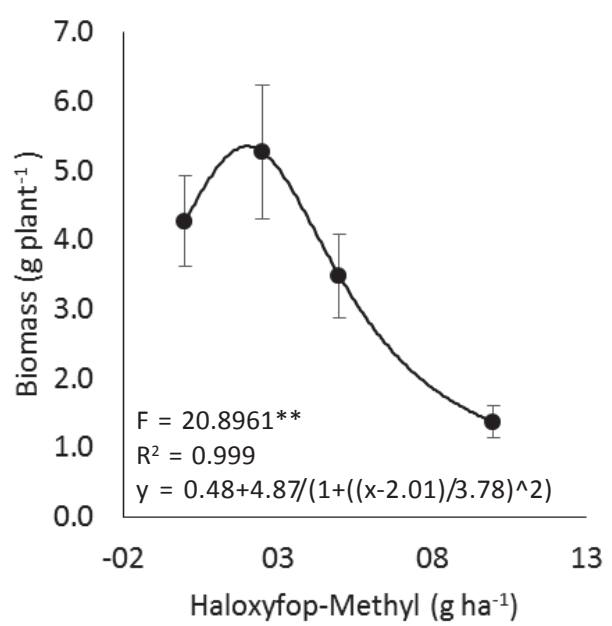

(A)

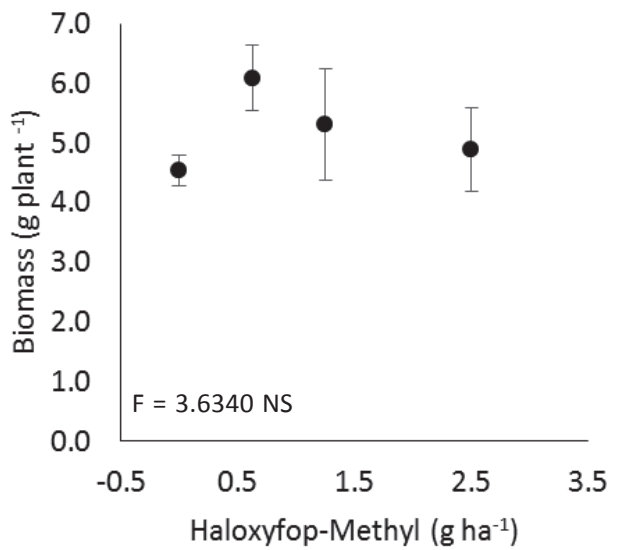

(B)

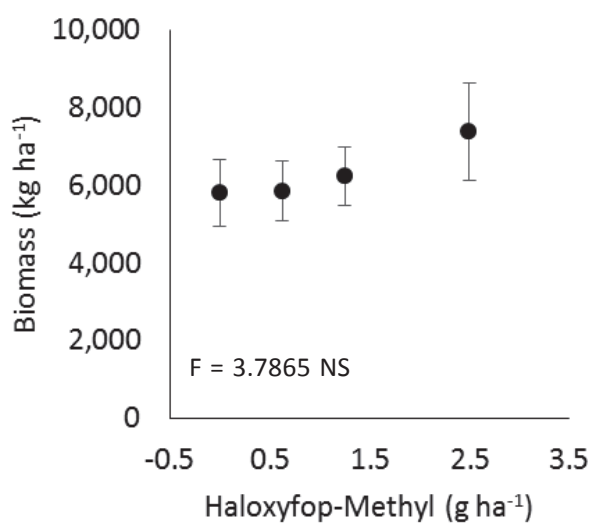

(C)

The data refer to mean \pm standard error $(\mathrm{n}=$ four replications, with four readings; $(\mathrm{p}<0.01)$.

Figure 2 - Accumulation of biomass of maize plants. (A) and

(B) Experiments in a greenhouse - evaluation at 21 DAA.

(C) Experiment in a yield area - evaluation after 150 DAA of haloxyfop-methyl. 

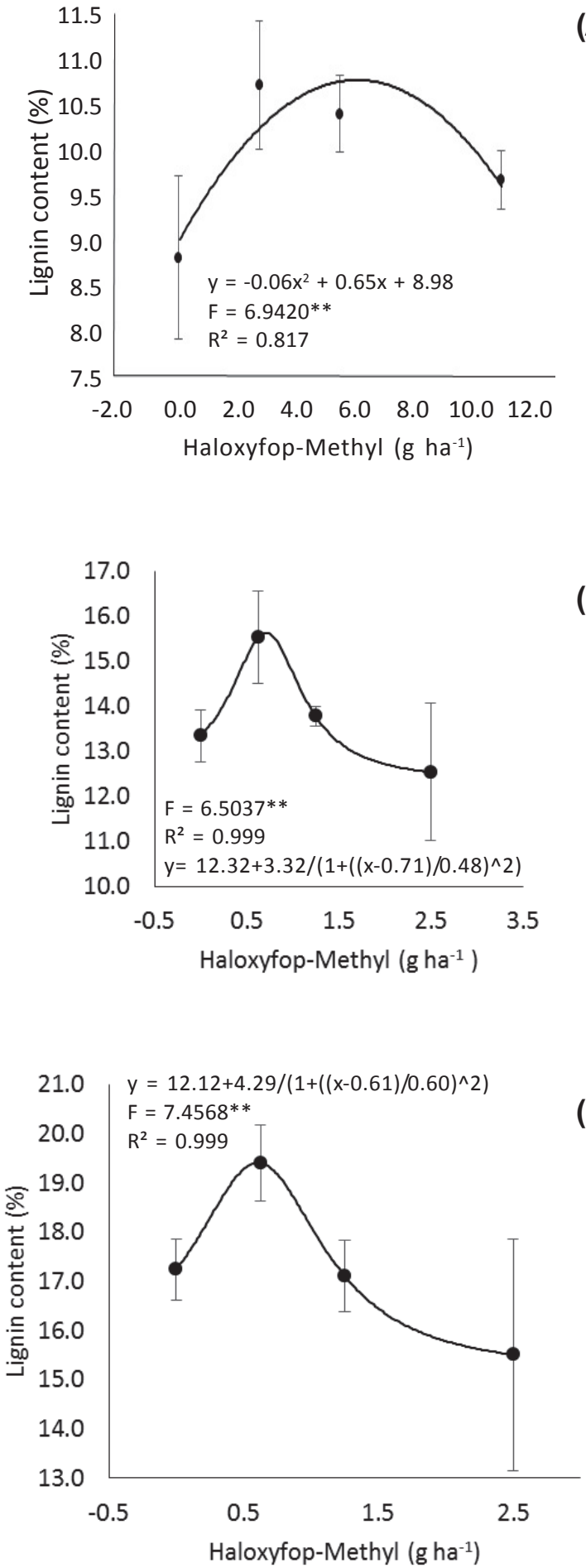

The data refer to mean \pm standard error $(\mathrm{n}=$ four replications, with four readings; $(\mathrm{p}<0.01)$.

Figure 3 - Lignin content of the maize plants. (A) and (B) Experiments in a greenhouse - evaluation at 21 DAA. (C) Experiment in a yield area - evaluation after 150 DAA of haloxyfop-methyl. nonlinear Lorentzian model, demonstrating that the application of an underdose of haloxyfop-methyl interferes in the lignification rate of maize plants. The concentrations of 0.625 and $1.25 \mathrm{~g} \mathrm{ha}^{-1}$ significantly increased lignin content in a greenhouse in 16.3 and $3,2 \%$ in relation to the initial concentration. The observed lignin increase can be interesting in some cases, as many authors have found that vegetable residues with higher contents are decomposed more slowly, compared to plants of lower levels (Floss, 2000; Sainju et al., 2007; Oliveira et al., 2009; Teixeira et al., 2010).

Underdoses of haloxyfop-methyl applied in the yield area resulted in lignin contents of $17.2 \%$ ( $0 \mathrm{~g} \mathrm{ha}^{-1}$ of haloxyfop-methyl), $19.4 \%$ (0.625), 17.1\% (1.25) and 15.5\% (2.5). These values were higher than those analyzed in the greenhouse, and one hypothesis suggested it is due to the fact that the analyses were carried out at different stages of maturity of the crop, as observed by other authors (Fukushima et al., 2000).

With regard to the values related to lignin found after application of the underdoses of haloxyfop-methyl in the yield area, it was observed that only an underdose of $0.625 \mathrm{~g} \mathrm{ha}^{-1}$ of the herbicide interfered in the increased rate of lignification of maize plants; a similar profile was observed for sugarcane with underdoses application of the herbicide glyphosate in a yield area (Meschede et al., 2012). Lignification, although a particular genetic trait for each of the plants, has a metabolic regulation which allows it to be manipulated by both extrinsic factors as by the regulation of genes that are interconnected to the biochemical pathways for synthesis and/or degradation of such polymer complex (Shi et al., 2012).

To evaluate the decomposition of maize stover, linear regression models were adjusted for the underdoses of haloxyfop-methyl applied (Figure 4). According to the linear regression intersection coefficient, the initial amount of residual stover was 8,383.6, 8,754, 6,213.6 and $8,609.9 \mathrm{~kg} \mathrm{ha}^{-1}$ for underdoses $0,0.625$, 1.25 and $2.5 \mathrm{~g} \mathrm{ha}^{-1}$ of haloxyfop-methyl, respectively. The line slope coefficient resulted in a daily decomposition of maize stover of $41.842,39.621,20.473$ and $44.195 \mathrm{~kg} \mathrm{ha}^{-1}$ for 

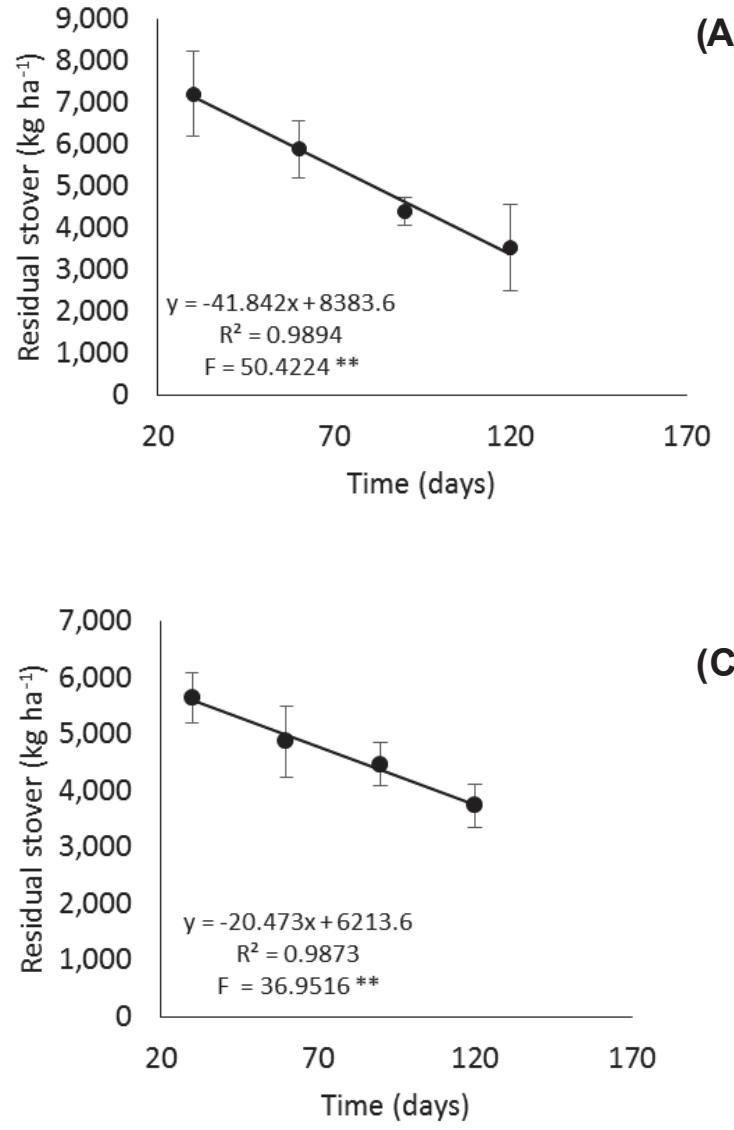

(A)

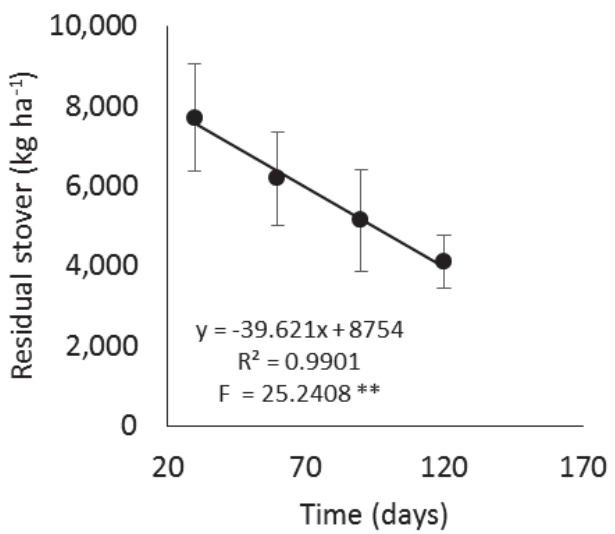

(C)

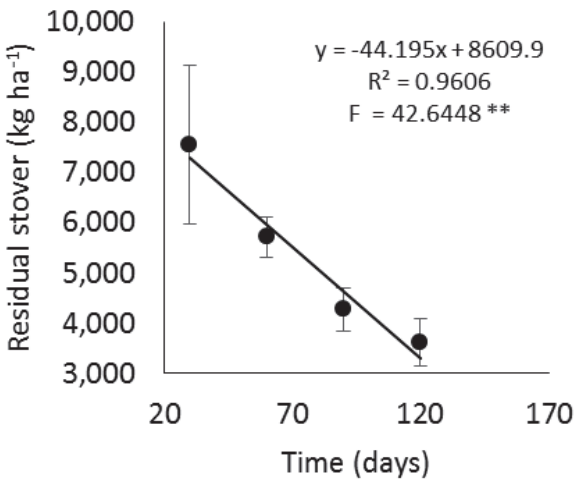

(B)

(D)

The data refer to mean \pm standard error $(\mathrm{n}=$ four replications, with four readings; $(\mathrm{p}<0.01)$.

Figure 4 - Decomposition of residual stover in the yield area, due to time: (A) 0.0 ; (B) 0.625 ; (C) 1.25 ; and (D) $2.5 \mathrm{~g}^{-1}$ haloxyfop-methyl.

underdoses $0,0.625,1.25$ and $2.5 \mathrm{~g} \mathrm{ha}^{-1}$ of haloxyfop-methyl, respectively. The data demonstrate that for higher underdose applied, daily decomposition of residual stover was higher. These results contributed to explain that, after a period of 120 days for underdoses $0,0.62,1.25$ and $2.5 \mathrm{~g} \mathrm{ha}^{-1}$ of haloxyfop-methyl there was a decomposition of 51, 47, 34 and $52 \%$, respectively.

The experiment with the underdoses in maize crops showed that there was an increase in the speed of the residual stover decomposition for the highest concentration of haloxyfop-methyl (Figure 4), reducing the time of mulch remaining on the soil surface and the release of nutrients (Leite et al., 2010).

Casa et al. (2003), when assessing maize residual stover decomposition in the Brazilian city of Passo Fundo, in Rio Grande do Sul, have reported decomposition of only $10 \%$ in the same period of 120 days. The differences observed differences can easily be explained by climatic changes during the period of testing, and especially low temperatures that directly interfere in microbial activity in the soil, which are responsible for the decomposition of organic matter (Berg, 2000).

Therefore, underdose $0.625 \mathrm{~g} \mathrm{ha}^{-1}$ in a greenhouse promotes an increase in lignin content, with no change in the unwanted growth of maize plants. In the yield area, the concentration of $0.625 \mathrm{~g} \mathrm{ha}^{-1}$ of haloxyfopmethyl increased lignin content in plants, without interfering with the undesired growth and yield of plant biomass, helping to delay the rate of decomposition of the residual stover. 


\section{REFERENCES}

Aratani R.G. et al. Desempenho de semeadoras-adubadoras de soja em latossolo vermelho muito argiloso com palha intacta de milho. Rev Bras Eng Agric Amb. 2006; 10:517-22.

Andreotti M. et al. Produtividade do milho safrinha e modificações químicas de um latossolo em sistema plantio direto em função de espécies de cobertura após calagem superficial. Acta Sci Agron. 2008;30:109-15.

Berg B. Litter decomposition and organic matter turnover in northern forest soils. For Ecol Manage. 2000;133:13-22.

Cabané M. et al. Condensed lignins are synthesized in poplar leaves exposed to ozone. Plant Physiol. 2004;134:586-94.

Caires E.F. et al. Calagem superficial e cobertura de aveia preta antecedendo os cultivos de milho e soja em sistema plantio direto. Rev Bras Cienc Solo. 2006;27:1075-83.

Calabrese E.J., Blain R.B. Hormesis and plant biology. Environ Poll. 2009; 157:42-8.

Casa R.T. et al. Decomposição dos restos culturais do milho e sobrevivência saprofítica de Stenocarpella macrospora e Stenocarpella maydis. Fitopatol Bras. 2003;28:355-61.

Cedergreen N. et al. Improved empirical models describing hormesis. Environ Toxicol Chem. 2005;24:3166-72.

Chioderoli C.A. et al. Consorciação de braquiárias com milho outonal em plantio direto sob pivô central. Eng Agr. 2010;30:1101-9.

Cox Júnior L.A. Hormesis without cell killing. Risk Anal. 2009;29:393-400.

Eckardt N.A. Probing the mysteries of lignin biosynthesis: the crystal structure of caffeic acid/5-hydroxyferulic acid 3/5o-methyltransferase provides new insights. Plant Cell. 2002;14:1185-9.

Federação Brasileira de Plantio Direto na Palha FEBRAPDP. Evolução da área de plantio direto no Brasil Ponta Grossa: 2013. Acesso em 03 jul. 2013. Disponível em: http://www.febrapdp.org.br/download/PD_Brasil_2013.I.pdf

Floss E. Benefícios da biomassa de aveia ao sistema de semeadura direta. Rev Plantio Direto. 2000;57:25-9.

Fukushima R.S. et al. Extração da lignina e emprego da mesma em curvas de calibração para a mensuração da lignina em produtos vegetais. Rev Bras Zootec. 2000;29:1302-11.

Gomes L.S. et al. Resistência ao acamamento de plantas e ao quebramento do colmo em milho tropical. Pesq Agropec Bras. 2010;45:140-5.

Jasper S.P. et al. Aplicação em subdose do haloxyfop-methyl na aveia-preta. Cienc Rural. 2015;45:637-43.

Planta Daninha, Viçosa-MG, v. 34, n. 3, p. 509-516, 2016
Leite L.F.C. et al. Decomposição e liberação de nutrientes de resíduos vegetais depositados sobre Latossolo amarelo no cerrado maranhense. Rev Cienc Agron. 2010;41:29-34.

Meschede D.K. et al. Teores de lignina e celulose em plantas de cana-de-açúcar em função da aplicação de maturadores. Planta Daninha. 2012;30:121-7.

Morrison I.M. A semi-micro method for the determination of lignin and its use in predicting the digestibility of forage crops. J Sci Food Agric. 1977;23:455-63.

Oliveira M.B. et al. Teor de Lignina em Plantas de Eucalyptus urophylla S. T. Blake Tratadas com Fitorreguladores. Silva Lusitana. 2009;17:51-7.

Penati M.A. et al. Número de amostras e relação dimensão: formato da moldura de amostragem para determinação da massa de forragem de gramíneas cespitosas. Rev Bras Zootec. 2005;34:36-43.

Rendina A.R. et al. Inhibition of acetyl-coenzyme A carbozylase by two classes of grass-selective herbicides. J Agric Food Chem. 1990;28:1282-7.

Sainju U.M. et al. Cover crop effect on soil carbon fractions under conservation tillage cotton. Soil Till Res. 2007;96:205-18.

Sazaki Y., Nagano Y. Plant acetyl-CoA carboxylase: structure, siosynthesis, regulation and gene manipulation for plant breeding. Biosci Biotechnol Biochem. 2004;68:1175-84.

Schabenberger O. et al. Statistical tests for hormesis and effective dosagens in herbicide dose response. Agron J. 1999;91:713-21.

Silva J.C. et al. Efeito hormese de glyphosate em feijoeiro. Pesq Agropec Trop. 2012;42:295-302.

SYSTAT SOFTWARE Inc - SSI. Sigmaplot for Windows, version 10, 2006. Disponível em: http:// www.systat.com.products/sigmaplot. Acesso em: 15 jan. 2016.

Shi H. et al. Overexpression of cotton (Gossypium hirsutum) dirigent 1 gene enhances lignifications that blocks the spread of Verticillium dahlia. Acta Biochim Biophys Sin. 2012;44:555-64.

Tardif F.J. et al. Resistance to acetyl-coenzyme a carboxylaseinhibiting herbicides endowed by a single major gene encoding a resistant target site in a biotype of Lolium rigidum. Austr J Plant Physiol. 1996;23:15-23.

Teixeira C.M. et al. Liberação de macronutrientes das palhadas de milheto solteiro e consorciado com feijão-deporco sob cultivo de feijão. Rev Bras Cienc Solo. 2010;34:497-505.

Velini E.D. et al. Glyphosate applied at low doses can stimulate plant growth. Pestic Manage Sci. 2008;64:489-96. 